Island Studies Journal, Vol. 11, No. 2, 2016, pp. 369-380

\title{
From medieval Dar al-Islam to contemporary Malta: rahl toponymy in a wider western Mediterranean context.
}

Charles Dalli

University of Malta, Malta

charles.dalli@um.edu.mt

\begin{abstract}
The diffusion of rahl placenames in Andalus and the islands of Majorca, Sicily and Malta in the High Middle Ages has long been noted, studied, and served as the subject of scholarly debate. With the transition of these western Mediterranean lands from Islam to Christianity in the wake of the Iberian Reconquista and the establishment of the Norman Kingdom of Sicily, the rahl did not disappear, but rather became a staple of Christian colonization records in Majorca and Sicily. The same cross-cultural process extends to the example of Malta, where the survival of an Arabic dialect arguably assisted the retention of the rahl as a living model for placenaming. The paper argues that the rahl toponym, originally representing a small-scale and individual unit, lent itself particularly well in the insular contexts of the medieval Christian expansion, fitting flexibly in the wider framework of cultural hybridization.
\end{abstract}

Keywords: Andalus, island, Malta, medieval, placenames, raḥl, Sicily

(C) 2016 - Institute of Island Studies, University of Prince Edward Island, Canada.

\section{Introduction}

Between the eleventh and the thirteenth centuries, the western Mediterranean basin saw the key passage of the main islands and sea routes from Muslim to Latin Christian control. The Norman conquest of the largest Mediterranean island of Sicily (1060-1090), closely followed by the annexation of the Maltese islands to the newly-formed Norman domains governed by Roger I of Hauteville, ensured the Latin Christian control over the strategic central Mediterranean crossroads. The conquest of Djerba laid the foundations for a short-lived Norman overlordship which extended ambitiously to the African coastline under Roger II. In the western Mediterranean, the expansion of the Crown of Aragon in 1229 with the conquest and colonization of the main Balearic island of Majorca completed the transformation of the regional equilibrium. The Latin Christian expansion into former Muslim lands presents a framework for the study of placenaming behaviour in a period of major transition. Although the framework is neither uniform nor unified, given the complex interaction of particular mainland and island communities along and across the main lines of Muslim-Christian engagement, and the multiple forces at play, it holds forth interesting examples of evolving systems of personal, collective and spatial nomenclature in a relatively cohesive picture of transition to Latin Christian rule. Moreover, it provides materials for the study of changing nomenclature in particular island contexts, enabling the present author to ask a specific question: what was special about these islands to encourage the use of a particular toponymy? 
The direction taken by the present investigation in answering this question is threefold. It investigates the late medieval Maltese corpus of rahl (Maltese: Rahal) placenames, many of which survive to this day, contextualizing the documentation within the framework of small island studies. It then moves to draw insights from other island contexts along different parts of the western Mediterranean crescent created by Latin Christian expansion. The final part of the essay puts the information through a 'small island' lens. The proliferation of rahl toponyms in Muslim Spain and Sicily, two theatres of Christian high medieval reconquest, was also reflected in Latin-language records generated in the wake of that expansion, including registers of land divisions, notarial contracts, and other documents where the careful attestation of local toponymy was necessary. The toponym would undergo a number of mutations, frequently via attempts at Latinization. By contrast, rahl toponyms in north Africa and the Middle East were rare. The ninth century treatise attributed to Ibn Qutayba (d. 276/ 889), Kitāb al-rahl wa l-Manzil, utilized in its title two common words which became village toponyms in Muslim Sicily, utilized them in the sense of camel-saddle and dwelling-place. In this latter sense, manzil was still in use in late medieval Maltese Arabic.

\section{The rahl toponym}

The rahl, from Arabic al-rahl, together with other words like qarya and manzil, came to enjoy widespread usage in the Arabic toponymy of Muslim Spain and Sicily. The process leading to common acceptance and usage of the term as a toponym was rather tortuous, considering the original Arabic etymology of rahl as 'camel saddle', and of rahhāal to denote 'someone skilled in saddling a camel'. By extension, rahl came to mean a 'stopover', and the connection with travel became evident in the word rihla for 'journey' (and, in literary contexts, 'travel description'); and the use of rahhāl as 'seasoned traveller', or even 'globetrotter' (Wehr, 1979, p. 383; Netton, 2012).

Scholarship on al-Andalus has been controversially divided on the nature of the rahl. One approach, inspired by the model of incastellamento, represented prominently by Pierre Guichard, has defined the alqarya as a collective rural community and the rahl as a private establishment. A contrasting, 'Arabist' approach developed by Mikel Epalza and M. J. Rubiera, has instead taken the etymological route to the numerous rahl locations recorded in the land divisions of the territories of the Reconquista, taking it to denote simply a livestock station (Barceló, 1985-6, pp. 240-241; Glick, 1995, pp. 22-26). These irreconcilable positions have not been echoed in the study of central Mediterranean usage of the same term rahl. There is a consensus on the definition of rahl as a rural estate for both high medieval Sicily and Malta. In particular, the term rahl in Sicily competed with manzil. In the case of Malta, it seems to have had a more exclusive role: rahl is defined as farmstead or country estate. In Sicily and Malta, it is assumed that the rahl was an original farmstead or estate. The repartimiento, or land division records, of the kingdoms forming the Crown of Aragon, including Valencia and Majorca, as well as the kingdom of Murcia (which was absorbed by Castile), provide the major corpus of rahl toponymy for al-Andalus. The major collection of Sicilian rahl placenames is the surviving administrative records of the estates of Monreale abbey, covering some $1,200 \mathrm{~km}^{2}$, where numerous rahl estates are listed. Rural establishments whose foundation predated the Christian conquest, frequently still bearing the name of a 'primordial' Muslim owner or founder, were now integrated into the wealthy endowment of the newly-erected Christian abbey. 


\section{The Maltese rahl}

The word rahl features prominently in late medieval and modern Maltese toponymy. Unlike the Spanish and Sicilian contexts, where rahl competed with other terms like alquería (from Arabic al-qarya), aldea (from Arabic $a l-d a y^{c} a$ ), and manzil, in the Maltese archipelago the rahl toponym remained the exclusive way to refer to the village, with harat (Arabic 'quarter') denoting a hamlet. The nomenclature of placenames in the Maltese islands is predominantly Arabic in origin, and reflects the archipelago's history between the ninth and eleventh centuries, when it was politically part of the Muslim world as an offshoot community of the emirate of Sicily. As part of the Muslim conquest of Byzantine Sicily, initiated in 827 and concluded by 902, the Maltese islands were besieged and taken in 869-870. There followed a long period during which, by some accounts, the island of Malta was left partly or even totally uninhabited, with the resettlement of the main island of Malta and the rebuilding of its town taking place in the wake of a Muslim colonization effort dating from around 1048. In an essay on toponymy, this detail is important as it provides us with a potential terminus post quem for the evolution of Malta's Arabic toponymy. The chronology is not as solid as would seem at face value; in particular, it is hard to explain how a relatively large island sixty miles off Sicily possessing reasonable resources was left uninhabited and undefended for more than a century. The controversial image given by the fifteenth century geographer Ibn ${ }^{\mathrm{c}} \mathrm{Abd}$ al-Mun ${ }^{\mathrm{c}} \mathrm{im}$ alHimyari of the island of Malta conquered and left 'an uninhabited ruin' by the Muslims in 870, in his Kitāb ar-Raw ${ }^{2}$ al-Mictar ('The Book of the Fragrant Garden'), was also echoed in the tenth century by the traveller Ibn Hawkal, who described the feral donkeys roaming the island, hunted down by visitors who exported them after feasting on local wild mutton. These visitors, some of whom were also honey collectors, timber cutters, or fishermen, constituted, according to the isolated textual indications, Malta's sole, sparse and seasonal human presence down to the mid-eleventh century. To date, Malta's archaeological investigators have not substantially challenged this version of Maltese history, despite the numerous questions it generates. The (re)population of Malta, by Muslim settlers and their ${ }^{c}$ abid, and then by Christians in the wake of the Norman annexation of the islands, gave rise to a settlement pattern which centred on the town (Mdina, Arabic madina) but also on a constellation of rural settlements, recorded with the Latin word casalia at the end of the thirteenth century. Unlike the transition 'from villa to village' postulated by Hodges and Francovich (2003, pp.12-15) for areas of Europe showing uninterrupted continuity from Roman times, in the case of a 'colonial' setup like Malta the original farmstead would act as a nucleus around which a settlement might grow.

The study of Malta's late medieval toponymy took off mainly in the 1970s with Wettinger's systematic search in the late medieval notarial records, a relatively small collection of registers covering the final one-third of the fifteenth century starting off with a register of deeds of 1466-67 (Wettinger, 2000). Noting that these records preserve the names of more rahl placenames than the other records suggested as inhabited settlements post-1400, Wettinger argued in 1975 that a number of rahl placenames already described deserted locations by time they were first recorded in the late Middle Ages. Wettinger's collection of late medieval toponyms showed that all the rahl placenames of Malta may be documented in records generated between about 1400 and the establishment of the Order of St John there in 1530. In contrast to one possible reference to a rahl placename on Pantelleria (Rakhali), and a dubious reference to one on Gozo ('Rachal Gubur,' which may have been mislocated there, 
instead of Malta, by a sixteenth century compiler), Malta's count of rahl toponyms may have exceeded a hundred, considering that a few may not have made it into the surviving records. In my view, considering what is known about medieval Malta's population levels, this count makes it almost certain that the high medieval proliferation of the toponym on Malta was not mainly connected to demographic settlement patterns, as suggested by Wettinger's 'lost villages' approach, but rather to agrarian property practices.

In view of the fact that rahl toponyms formed part of complete systems of toponymy which varied substantially from place to place, the 'isolation' of rahl names from the wider systems of regional or local toponymy within which they were adopted, embedded and allowed to evolve, has methodological limitations which cannot be overlooked.

The corpus of Sicilian rahl toponyms, said to consist of more than a hundred rahl toponyms (107 rahl and 18 manzil, according to Burman, 1991, p. 88), includes a relatively small number of localities where the prefix managed to survive in one form or other. The same remarks on the relatively limited modern descent of rahl toponyms in the Iberian context may be made from an observation of the corpus of rahl toponyms from Majorca and Valencia (Bofarull y Mascaró, 1856). This contrasts with the Maltese corpus, which still includes a substantial number of rahl toponyms in use to this day. When taken in conjunction with the Sicilian corpus of the Monreale estates, which yields around sixty firmly documented rahl placenames, the Maltese corpus of ninety rahl placenames compares well despite the disparity in both geographical size and importance between the island of Sicily and the Maltese archipelago. Wettinger's documentary base was mainly sourced in notarial deeds dating from the late fifteenth to the early seventeenth century. Considering the relatively limited survival rate of Maltese notarial records, representing mainly the final one-third of the fifteenth century, there may originally have been well over a hundred rahl placenames in Malta. Almost all rahl placenames bore the name of an individual, possibly an allusion to an original estate owner and/or founder. In modern Maltese, rahl placenames are invariably shortened in speech from rahl to hal (Maltese Hal, or variants of this in the case of placenames beginning with consonants which assimilate, such as Hat-Tarxien, Has-Sajjied, Haż-Żabbar). Some of the toponyms have survived as uninhabited countryside locations, or as a cluster of farmsteads. The process of village desertion was already under way in the late Middle Ages (Wettinger, 1975). More than a quarter of them also double up as family names documented in militia records of the early 1400s, and a good number of rahl toponyms are in use to this day, including the populous central 'three villages' (tliet irћula) of H'Attard, Hal Balzan, and Hal Lija. With the urbanization of Malta's agrotowns in the final century of the Order's rule in Malta, a number of raḥl placenames have, since, the eighteenth century, even worn the coveted mantle of an urban title, having been declared respectively as towns by the eighteenth century Grand Masters Pinto (Hal Qormi, formally Città Pinto), Rohan (Haż-Żebbug formally Città Rohan), and von Hompesch (Haż-Żabbar, formally Città Hompesch), with the toponym's etymological connection to the raising of livestock in no way impeding the passage to 'official' urban status. The larger rahal/rhula in Malta today are effectively quasi-cities, and a

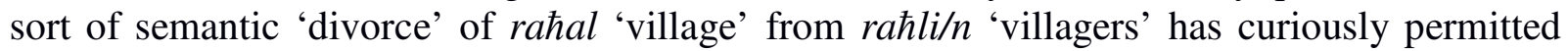
the former word to thrive, even with reference to the largest communities by population in Malta, which incidentally are not even rahl/ Hal placenames, namely Birkirkara, il-Mosta, inNaxxar, and San Pawl il-Bahar; their residents would not hesitate in referring to their locality

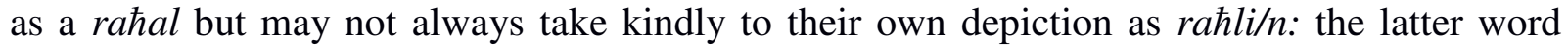
carries the secondary, derogatory connotation of rusticity or backwardness. 


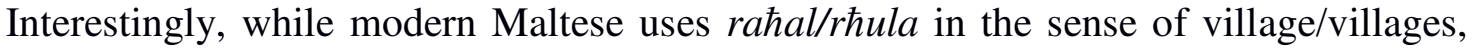
and rahli/rahlin as villager/s, it also retains something of the original Arabic etymology of the term, as indicated by the word merhla for flock (the broken plural Mriehel 'the Flocks' being a toponym in itself). In Andalusi Arabic, though not in modern Maltese, the root was semantically extended to denote sharing of camp, and more generally social intercourse (Corriente, 1997, p. 204). While the Maltese word for farmer is bidwi (from Arabic badawi,

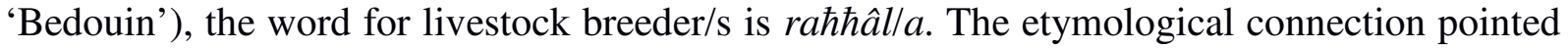
out between rahl and livestock breeding or animal husbandry in Andalus, and underlined for fourteenth-century Sicily by Backman, seems to be borne out by the Maltese case as well. The usage of the related toponym marhala / marạhil al-baqar, translated in the Latin mandra vaccarum on the Monreale estates, indicates a similar relationship. The Latin rendering of rahl as casale would also confirm the pattern of evolution of the toponym into a placename for rural settlements. The link between the rahl-type estate and private ownership was mainly marked by the construct state with personal nomenclature, particularly names of male individuals, nicknames, or family/clan names. Marks of ownership could also be physical, such as the admittedly exceptional reference to the medieval rahl of the Bordino family where a column bearing their coat of arms was recorded. The presence of numerous Muslim and Christian personal names, as well as a few Jewish ones, in Malta's rahl toponymy is a striking feature, indicating that the diffusion of the toponym probably coincided with a period of religious coexistence in the twelfth and early thirteenth centuries. The redistribution of former Muslim-held lands, in Malta as in Sicily, may have given rise to further strategies of renaming in some cases. In the fifteenth century, Maltese rahl toponyms yield a count of thirty-four out of around fifty inhabited rural centres. On medieval Gozo, the absence of rahl toponyms was not the effect of the success of rival toponyms for rural settlement, but rather that of an empty countryside reflected in the population's concentration in the hilltop castle and Rabat.

\section{The Sicilian rạl}

In contrast to the active use of the rahl/rahal toponym in Malta, due to the fact that it is also part of the native language there, its survival in the toponymy of present-day Sicily is mainly as a fossil from the island's distant chapter of Muslim history, in the names of towns such as Regalbuto, Racalmuto, Raffadali, and Resuttano. The 'mother island' of Sicily, a hundred times or so the size of Malta with vastly superior resources, is also the heartland of a central Mediterranean insular constellation which has been redefined by Baldacchino (2015) as 'the Sicilian archipelago'. The Muslim world saw Sicily as 'the daughter of al-Andalus' (Kapitaikin, 2013), and at its greatest extent the western Muslim world exploited this Sicilian archipelago as a bridgehead between its different parts. A geographical and cultural continuum between al-Andalus and the Maghrib was created, permitting the flow of ideas and institutions alongside the exchange of people and goods, epitomized in the world of the Cairo Geniza, but also to an extent in the Arabic culture and administration of Norman Sicily. The twelfthcentury documents in Arabic, Greek and Latin edited (imperfectly) in the nineteenth century by Salvatore Cusa, and now systematically studied and prepared for a new edition by Alex Metcalfe and Jeremy Johns, attest to the proliferation of rahl toponymy in Norman Sicily, including at least sixty rahl toponyms from the estates pertaining to Monreale abbey (Metcalfe, 2003, pp. 188-220). The chief registers called jaridat recorded estate boundaries or lists of villeins attached to the establishments concerned. The 'royal dīwān' of Norman Sicily 
kept Greek-Arabic estate registers detailing boundaries, the dafātir al-hudūd ('registers of boundaries'), which like the repartimiento records of the Crown of Aragon provide a major source of rahl toponyms. As various authors, notably Illuminato Peri (1965) and Henri Bresc (1986), have shown, following the expulsion of the Muslims from Sicily, large tracts of countryside were left uninhabited or sparsely settled, and rahl toponyms could sometimes be found integrated into larger structures belonging to the latifondo-holding feudal aristocracy. Later medieval Sicily's casalia have not attracted systematic study. Unlike large parts of western Sicily, a substantial concentration of villages was to be found in the north-eastern Val Demone, amply documented in the late medieval records. The decline charted by Bresc from more than 1200 villages prior to 1250 , already halved by the late thirteenth century, to about a hundred in the fourteenth century, was certainly dramatic. There is little doubt that the rahl had been one of the principal victims of the earlier transformation of the Sicilian countryside. The rahl as a living structure typically representing a rural estate with families of villeins attached to it, in a sense, was one symbol of the Norman system in Sicily, and the collapse of the system was its death knell.

The density of rahl toponymy on the Monreale estates, some 50 per $1,000 \mathrm{~km}^{2}$, is still relatively low in comparison to the Maltese one, which would theoretically rise to 360 per $1,000 \mathrm{~km}^{2}$. Nevertheless, the dissimilarities in the documentary materials concerned would urge a cautious approach. The count of rahl-type toponyms for the whole of medieval Sicily has not been systematically undertaken, but Michele Amari (1859) was able to compile a corpus of almost 140 straightforwardly rahl toponyms by widening the search to include sources from the 1200s. The Latinization of the placename into Rahalis, or even rahallus, for a while extended the life-span of the toponym beyond the uprooting of the remaining Muslims from Sicily in the early thirteenth century (Backman, 2002, p. 17).

Defined as both domaine foncier and village, the rahl together with the $d^{a} y^{c} a$ were suggested by Bresc as the basis of land redistribution in Muslim Sicily as carried out by the authorities among state officials. It is unclear how, and when, the diffusion of the rahl system across Muslim Sicily took off, but the Fatimid efforts at incastellamento in the island decreed around 966-7, as described by al-Nuwayrī, would suggest an existent system of rural settlement by the late tenth century (Amari, 1935, p. 314; Maurici, 1992, p. 63). Whether this system already included the rahl is unclear, despite its unquestionably Arabic toponymy. The generally conservative character of rural toponyms would suggest that the rahl was firmly embedded in the island's toponymy by the eleventh century to survive through the instability of the Norman conquest and the establishment of a new Latin Christian feudal-colonial aristocracy, retaining a significant role in the 'new world' which was brought into being by the twelfth century.

The question of defining the characteristics of the Sicilian rahl has occupied historians since the days of Rosario Gregorio. Johns (2002, p. 6) has noted "the essentially Islamic context in which alone the Arabic administration of Norman Sicily can be understood". Moreover, details on how this system of cross-cultural adaptation are, at best, limited. Royal gifts of rahl-type estates complete with lists of men included in the transfer, necessitated meticulous keeping of boundary details, for which the central administrators at Palermo must have necessitated the consultation of local sources of written and/or unwritten knowledge. The entries typically give precious little information on the nature and structure of the rahl. The Monreale corpus provides an essential source for the reconstruction of twelfth-century Sicilian toponymy (Metcalfe, 2003, pp. 188-220). The Monreale list of 1183 gives eight rahl toponyms 
out of a total of fifty-two entries, with villein totals of 11, 12, 13, 4, 6, 1, 7 and 3 (these men comprised both the so-called ridjāl al-mahallāt or 'men of the village/s', and muls or 'migrants') attached to the said rahl-type estates (Johns, 2002, pp. 168-9). These modest figures help indicate the scale of the estates concerned, at least in terms of the unfree manpower associated with the productive activities of the estate. One should not exclude the possibility that some rahl toponyms bearing Christian names may indicate not simply the transfer of existent units under new Christian ownership, but a continued process of foundation of new rahl establishments by the Christian conquerors themselves. Norman practices connected with the foundation of new rahl properties or the extension of existent rahl-type estates in different parts of Sicily remain practically unknown, although there is reason to believe that more general strategies aiming at property improvement and consolidation would also have been applicable. The innovative element in Norman placenaming practices consisted, in part, in supplying a new personal nomenclature reflecting the Latin Christian ruling class supplying the chief landowners and propertied families. Nevertheless, by and large the documents of the royal diwān also underline the conservative tendency to preserve the existent toponymy where possible, and at any rate to continue to prefix extant or new toponyms with the familiar Arabic terms. The adaptation involved in rendering Arabic nomenclature in Greek and Arabic provides, in itself, fascinating insights into the mechanisms of cultural translation, as well as revealing a certain degree of linguistic flexibility.

\section{The rạ̣l in al-Andalus}

The same process of cultural translation can be seen in the wholesale acquisition of the Arabic toponymy by the Latin Christian conquerors in the 'Catalan-Aragonese' theatre of the Reconquista. In southern Spain it is estimated by Messner (in Jayyusi, 1994, p. 452) that at least one-fifth of all modern toponyms per $1000 \mathrm{~km} 2$ are of Arabic origin. Summarizing the debate emerging from the toponymy of Muslim and post-reconquest Andalus, Glick underlined the 'universality' of the so-called 'hiṣn/qarya complex' ('castle/village complex') across much of Andalus, and fitted the discussion of rahl and alquería within that wider framework (Glick, 1995, pp. 15-22). Interestingly, the general distribution of rahl and alquería localities in both Valencia and Majorca would show that the proportion of the former to the latter was roughly one-third to two-thirds (Glick, 2007, p. 46).

As noted above, the Llibre del repartiment (land division registers) drawn up following the Catalan-Aragonese conquests provide an impressive corpus of rahl toponyms in former territories of al-Andalus. Sanchis i Martínez (1999) located 120 rahl placenames in the Llibre del repartiment of the Kingdom of Valencia, conquered in 1238. The repartiment of the island kingdom of Mallorca alone documents more than 200 other rahl placenames. Transcribed as rahal, the toponym was soon used interchangeably with that for alquería by the Catalans, who tended not to distinguish between the two. The debate among scholars of al-Andalus concerning the correct definition of rahl has also underlined the limitations of the available documents. The debate has also brought fruitfully to the surface some radical historiographical differences (for a useful summary see Glick, 1995). For Epalza, the toponym's link to cattle rasing seems unquestionable (Epalza, 1996, p. 185). On the other hand, for Guichard, the rahl was a private property, which in the case of the Valencian countryside fulfilled the needs of a private aristocratic landholding in an otherwise tributary landscape dominated by alquería 
village communities defended by a ḥiṣn, or castle (Guichard, 1989; 2001, pp. 518-522). To underline his thesis, Guichard cited the Mallorcan rahl toponyms, which clearly prefix the names of individual owners. Critics of this position, notably Rubiera, have insisted on a broad and simple definition of rahl as a cattle corral. Rubiera also pointed out the existence of 'los falsos rafals', terms like raval (Castilian arrabal), as well as the ubiquitous reals/reales, from the Arabic riyad 'garden' or 'orchard'. Further confusion was also created by the variety of renderings of rahl- the Catalan rafal, rafalet, rafel, and even rafallo; and the Castilian raal. Nevertheless, this expanding terminology among the Christian conquerors underlines precisely the process of cultural translation and adaptation which has already been noted in Sicily. The success of the rahl toponym may well have been the very way it ambiguously lent itself to these adaptations in different contexts, including possible misapplications (or, in Rubiera's view, 'falsifications'.) More creatively, at the end of the fifteenth century, 'Rafal' was still felt to be 'Arabic' enough for it to be imaginatively transposed to Tunis. In the Valencian romance Tirant lo Blanc (1490) an old Moor who had endured captivity in Christian Cádiz, to be eventually set free by his Christian mistress, is finally able to repay his former owner's kindness by helping her daughter the damsel Plaerdemavida ("Pleasure-of-my-life"), who is led 'to the village of Rafal near Tunis' where she is assisted by the old man's daughter, and dressed up 'so that everyone would think she was a Moor' (Rosenthal, 1984, p. 452; the original text has "en hun loch qui prop de Túniç stava, qui·s nomenava Rafal”).

Interestingly, the repartiment of Mallorca revealed that the alquería tended to be almost twice the size of the rahl, extending on average for 7 jovates versus 4 (the jovate was originally the amount of land which could be ploughed in a day by a pair of oxen, and measured some 11.36 hectares). Therefore, on average the Mallorcan rahl, according to these estimates, did not exceed 50 ha (Glick, 1995, p. 133). Moreover, a good number of alquería (190) and rahl (65) toponyms on the island prefixed 'Beni-' clan names, reflecting a strong Berber-north African presence, and therefore indicating strong familial links reminiscent of links between family nomenclature and rahl names. (Glick, 1995, p. 133; 2007, pp. 46-48). I find the Mallorcan evidence on the relative smallness of the rahl useful in explaining the proliferation of the same toponym in other insular contexts, notably the Maltese one. 'Resistance' to Guichard's notion of the rahl as a private estate remains considerable in Spanish studies. As a measure of the 'global' extent of this 'resistance', one can take an eminent example from English-language scholarship on medieval Iberia. In 1988, noting the Latin form of rahl as rahallus in the Valencian documents, Robert I. Burns, a foremost authority on crusader Valencia, felt necessary to preface his Diplomatarium of the kingdom of Valencia with a note on the rahl's 'primary connection with livestock, as well as its lowly character, not confusing it with a private estate', insisting that the rahl $l$ was a simple structure used by cattle herders (Burns, 2014, p. xiii).

\section{Discussion}

I suggest that the dissent noted among scholars working with clashing definitions of rahl toponyms and their role, may itself provide a key to understanding the remarkable multicultural success of this simple term with a distant etymology. In the wake of the Latin Christian conquest, the loss of semantic distinctions between contiguous terms led to their widening usage. The processes of cultural translation and borrowing, exemplified in formal spheres in the Latinization of the term in Sicilian and Valencian royal charters, also extended 
to the creation of a range of terms within which more could easily fit than was possibly meant with the Arabic term rahl. The process of linguistic and semantic adaptation - termed in the Arabist critique a process of 'falsification' - underlines the hybridity of a toponym rooted in the Arabic verb for travel: a traveller's waystation, and by extension a shepherd's shelter. From this original meaning, echoing the camel-saddles of desert nomads, the term was then adopted to denote a structure associated with a more sedentary activity - the pursuit of agriculture, in the form of animal husbandry or stockraising. In particular contexts, it came to denote a private farmstead - even, arguably, a country estate of a notable. In the course of the Latin Christian expansion, in Norman Sicily and Malta, and apparently also in some cases in the Crown of Aragon, rahl/ rahal expanded its meaning from country estate to denote a lot more including, unambiguously in some contexts, references to permanent settlements. This semantic widening of the term seems to have been mainly the effect of the Latin Christian adoption of rahl as a term of acculturation. The hybridization of rahl with alquería in lands of the Crown of Aragon, but also in Sicily, where the term was incorporated in the names of towns, was therefore, according to this perspective I am suggesting, an effect of the way the Christian expansion in the western Mediterranean, kept in currency the Arabic toponym, considered relatively obscure anywhere else in the Arab world, and diluted its meaning and application widely enough for it to proliferate. The Maltese case ties together the etymological root of the term in its reference to livestock, with its exclusive widening and adaptation to refer to village communities. The evidence from Malta also underlines the tendency witnessed in Mallorca and Sicily, for the rahl to prefix the name of an individual, or some other element of personal nomenclature, a pattern which for the French historical school of al-Andalus strongly indicates the element of primordial private ownership.

These elements help shape a tentative answer which can now be proposed to the question: what encouraged this toponymy in these islands, by contrast with north Africa and the Middle East, to expand, and in the case of Malta to predominate to this day? References to livestock on these islands abound in medieval descriptions, and it is highly plausible that early (re)settlement was facilitated through allotments of parcels of property to enable stockraising. The names embedded with rahl prefixes may well record the original owners or early managers of these small rural enterprises. Faced with the challenges of enticing sufficient agricultural manpower for land cultivation, the encouragement of individual efforts in herding in islands which reportedly teemed with wild livestock promised much quicker results. It may also have suited the aspirations of migrant settlers who sought to acquire their own setup. The common factor underpinning the proliferation of rahl toponymy is the Christian expansion. Planted by the Muslims, the rahl ironically became a vehicle of the Christian conquerors and their followers, in the process of 'colonial' reorganization of territories taken and refashioned into Christian kingdoms. The toponym proved ambivalent enough to survive and be employed in various forms and renderings in the spoken and written languages of the new masters. Last but not least, in the case of Malta, the extraordinary success of the rahl toponym underlines the significance of the small island environment in adding further conditions to those generally faced by Latin Christian expansion: the small scale of the rahl may have worked in its favour in a small island environment, with its emphasis on individual input, while basically drawing on readily available resources. According to this view, the success of the toponym must have drawn on the material success of the structure it described.

The story of the rahl is one which links ancient nomadic, globetrotting people to a radically smaller-scale medieval world centred on the stockraiser, the sedentary farmstead and 
the village microcosm, the serfs and smallholders and the town-dwelling landowner proprietors. The foregoing conclusions on the diffusion of this toponym across the western Mediterranean region in the Middle Ages, and its lively survival on modern Malta, permit some engagement with fellow scholars of historical island toponymies. In the first place, the scarcity of land as the prime resource in a small island like Malta made the precise demarcation of land ownership and organization a primary concern, and the rahl toponym may have provided a simple and efficient way of mapping out the island's network of farmsteads/villages. That the toponym was prevalently tied to personal nomenclature would seem to support this concern with recording ancestry and/or proprietorship. Secondly, the survival of a spoken dialect of Arabic on Malta, and its evolution into modern Maltese, must have ensured that the rahl toponym would not simply be conserved as an embedded prefix in a fossilized rural toponymy, but would continue to have a life of its own, evolving in a way which is probably unmatched in any other part of the region where it was historically diffused. And thirdly, the way the toponym diffused and developed in modern Malta is itself a miniature version of that complex linguistic journey: it underlines how a regionally central yet small insular context could provide in relative isolation a protected environment where a medieval toponym originating in a distant culture could thrive in new ways among people who would never suspect where their rahal came from.

\section{References}

Amari, M. (1935). Storia dei musulmani di Sicilia. vol 2. Carlo Nallino, editor. Catania, Italy: R. Prampolini.

Amari, M., \& Dufour, A.-H. (1859). Carte comparée de la Sicile moderne avec la Sicile au XIIe siècle d'après Edrisi et d'autres géographes arabes. Paris, France: Lemercier.

Backman, C. R. (2002). The decline and fall of Medieval Sicily. Cambridge: Cambridge University Press.

Baldacchino, G. (2015). Lingering colonial outlier yet miniature continent: notes from the Sicilian archipelago. Shima: The International Journal of Research into Island Cultures, 9(2), 89-102.

Barceló, M. (1985-6). Vespres de feudals. La societat de Sharq al-Àndalus just abans de la conquesta catalana. La formació i expansió del feudalisme català. Estudi General: Revista de la Facultat de Lletres de la Universitat de Girona, 5-6, 237-51.

Bofarull y Mascaró, P. de (1856). Colección de documentos inéditos del Archivo General de la Corona de Aragón, XI. Barcelona, Spain: Archivo General de la Corona de Aragón.

Bresc, H. (1986). Un monde méditerranéen: économie et société en Sicile, 1300-1450. Bibliothèque des Écoles Françaises d'Athènes et de Rome, 262. (Vols. 1-2). Rome, Italy-Palermo, Italy: École Française de Rome \& Accademia di Scienze, Lettere e Arti di Palermo.

Burman, E. (1991). Emperor to emperor: Italy before the Renaissance. London: Constable and Robinson.

Burns, R. I. (2014). Diplomatarium of the Crusader Kingdom of Valencia: The registered charters of its conqueror, Jaume I, 1257-76. Princeton NJ: Princeton University Press.

Burns, R. I. \& Chevedden, P. E. (1999). Negotiating cultures: Bilingual surrender treaties in Muslim-Crusader Spain. Leiden, The Netherlands: E. J. Brill.

Corriente, F. (1997). A dictionary of Andalusi Arabic. Leiden, The Netherlands: E. J. Brill. 
Epalza, M. de, \& Rubiera, M. J. (1986). Estat actual dels estudis de toponimia valenciana d'origen àrab. In Xè Col.loqui General de la Societat d'Onomàstica Valenciana (pp. 420-426). Valencia, Spain: Conselleria d'Administració Pública de la Generalitat Valenciana.

Epalza, M. de (1996). Islamic social structures in Muslim and Christian Valencia. In P. Chevedden, D. Kagay \& P. Padilla (Eds.), Iberia and the Mediterranean world of the Middle Ages - vol. 2. (pp.179-190). Leiden, The Netherlands: E, J. Brill.

Francovich R., \& Hodges, R. (2003). Villa to village: The transformation of the Roman countryside in Italy, c.400-1000. London: Duckworth.

Glick T. F. (1995). From Muslim fortress to Christian castle. Manchester: Manchester University Press.

Glick T. F. (2007). Paisajes de conquista: cambio cultural y geográfico en la España medieval. Valencia, Spain: Universitat de València.

Gordón Peral, M. D. (Ed.) (2010). Toponimia de España. Estado actual y perspectivas de la investigación. Patronymica Romanica, 24. Berlin, Germany: de Gruyter.

Guichard, P. (1989). A propos des rahals de l'Espagne orientale. Miscelanea Medieval Murciana, 15, 9-24.

Guichard, P. (2001). Al-Andalus frente a la conquista cristiana: los musulmanes de Valencia, siglos XI-XIII. Valencia, Spain: Universitat de València.

Johns, J. (2002). Arabic administration in Norman Sicily. Cambridge: Cambridge University Press.

Jayyusi, S. K. (Ed.). (1994). The legacy of Muslim Spain. Leiden, The Netherlands: E. J. Brill.

Kapitaikin, L. (2013). The daughter of al-Andalus: interrelations between Norman Sicily and the Muslim West. Al-Masāq, 25(1), 113-34.

Maurici, F. (1992). Castelli medievali in Sicilia: Dai Bizantini ai Normanni. Palermo, Italy: Sellerio.

Messner, D. (1994). Further listings and categorizations of Arabic words in Ibero-Romance languages. In S. K. Jayyusi (Ed.), The legacy of Muslim Spain (pp. 452-456). Leiden, The Netherlands: E. J. Brill.

Metcalfe, A. (2003). Muslims and Christians in Norman Sicily. London: Routledge.

Netton, I. R. (2012). Riḥla. In Encyclopaedia of Islam, 2nd edn, Vol. 8 (p. 528). Leiden, The Netherlands: E. J. Brill.

Peri, I. (1965). Il villanaggio in Sicilia: Studi di storia medievale e moderna, No. 2. Palermo, Italy: Manfredi.

Rosenthal, D. H. (1984). Tirant lo Blanc by Joanot Martorell and Martí Joan de Galba. Baltimore MD: Johns Hopkins University Press.

Rubiera Mata, M. J. (1984). Rafals y raales; ravals y arrabales; reals y reales. Sharq alAndalus, 1, 117-122.

Rosselló i Verger, V.M. (2004). Toponímia, geografia e cartografia. Valencia, Spain: Universitat de València. 
Sanchis i Martínez, V. (1999) Els "rahals" del Llibre del Repartiment. Aguaits, 16, 7-16.

Wehr, H. (1979). A dictionary of modern written Arabic. (4th edn.). Wiesbaden, Germany: Harrassowitz Verlag.

Wettinger, G (1975). The lost villages and hamlets of Malta. In A.T. Luttrell (Ed.), Medieval Malta: Studies on Malta before the Knights (pp. 181-216). London: British School at Rome.

Wettinger, G. (2000). Place-names of the Maltese Islands. Malta: PEG. 